\title{
"COMO SE FOSSE UMA ELEIÇÃO PARA VEREADOR": DINÂMICAS PARTICIPATIVAS E DISPUTAS PARTIDÁRIAS NA CIDADE DE SÃO PAULO
}

\author{
LUCIANA TATAGIBA
}

KARIN BLIKSTAD

Este artigo representa um esforço de sistematização e análise da mobilização dos atores populares para a eleição de seus representantes na quarta gestão do Conselho Municipal de Habitação (CMH) de São Paulo. Consideramos as interfaces que sustentam o processo: a relação entre movimento social, partidos, governo, além de recuperarmos elementos que caracterizam a atuação dos representantes populares nesse conselho, que vem se consolidando como uma arena política relevante para o tema da habitação na cidade. Um dos principais achados da pesquisa refere-se à importância dos nexos e vínculos tecidos entre movimento, governos e partidos para a compreensão da dinâmica participativa e seus resultados. Nessa experiência vemos como as dinâmicas participativas bebem na fonte dos repertórios já conhecidos dos atores e se baseiam - não sem tensões e conflitos - em vínculos e lealdades já constituídas no decurso das disputas eleitorais travadas nos territórios para as eleições executivas e legislativas.

Palavras-chave: participação, democracia, movimento de moradia, Conselho Municipal de Habitação, governo, partidos.

Recebido: 21/05/2010 Aprovado: 05/09/2011

\section{"AS IF IT WAS A COUNCIL-MAN ELECTION": PARTICIPATORY DYNAMICS AND PARTY DISPUTES IN THE CITY OF SÃO PAULO.}

This article discloses and analyzes the mobilization of popular actors to elect their representatives in the fourth administration of the Conselho Municipal de Habitação (CMH - Municipal 
Housing Council) of Sao Paulo. We consider the relationship between social movement, parties, government, and also recover some facts that characterize the action of the representatives in this space, which is consolidating itself as a relevant political arena in the city's housing policy. One of the main findings of the research alludes to the importance of the connections and links between movement, governments and parties to understand the dynamic of participation and its results. We see the participation as a process that nourish itself from the actors' previous and familiar repertoires, and also build itself - not without tensions - from connections and loyalties already established in the previous executive and legislative electoral battles.

Keywords: participation, democracy, housing movement, Municipal Housing Council, government, political parties. 


\section{"COMO SE FOSSE UMA ELEIÇÃO PARA VEREADOR": DINÂMICAS PARTICIPATIVAS E DISPUTAS PARTIDÁRIAS NA CIDADE DE SÃO PAULO*}

Luciana Tatagiba

Karin Blikstad

No dia 4 de outubro de 2009, eleitores da cidade de São Paulo foram às urnas para escolher os dezesseis representantes das organizações populares de moradia que compõem o Conselho Municipal de Habitação (CMH). Havia cinco chapas na disputa: três delas encabeçadas por nomes historicamente vinculados ao movimento de moradia; uma identificada como a "chapa do governo" e outra como chapa "independente". Organizações do movimento de moradia, parlamentares, líderes partidários e membros do governo atuaram para eleger seus aliados. Em jogo estava a representação numa instância de participação que tem o poder legal de decidir sobre a política habitacional para a cidade, principalmente no que se refere ao atendimento à população de baixa renda. O resultado final apontou a vitó-

\footnotetext{
* Uma versão preliminar deste texto foi apresentada no Seminário Temático Legitimidade democrática, representação e participação, no $34^{\circ}$ Encontro Anual da Anpocs, em 2010. Agradecemos nessa ocasião a leitura atenta e os comentários de Bruno Reis, Fernando Weltman e Adrian Gurza Lavalle. A este último agradecemos, em particular, as argutas sugestões e o diálogo produtivo no decorrer da preparação deste artigo.
} 
ria da assim chamada "chapa do governo", que conquistou dez das dezesseis posições em disputa.

Neste artigo, descrevemos e analisamos esse processo eleitoral desde a montagem das chapas, a campanha de divulgação dos candidatos, a mobilização no dia da eleição, até os resultados finais do pleito. Até onde temos conhecimento, essa é uma pesquisa inédita na área da participação e dos conselhos.

Um dos principais achados da pesquisa remete à importância dos nexos e vínculos entre movimentos, governos e partidos para compreensão da dinâmica participativa e seus resultados. Como evidenciamos ao longo do texto, as relações entre lideranças dos movimentos, parlamentares, representantes partidários, agentes do governo, tão presentes no dia a dia dos bairros pobres, conformaram o quadro de partida para as disputas no CMH e influenciaram fortemente o desfecho das eleições dos conselheiros populares. A própria 176 criação desse conselho resultou da articulação de setores do movimento de moradia, militantes do Partido dos Trabalhadores e membros da gestão de Marta Suplicy (2001-2004), que, a partir de uma forte convergência de interesses e projetos facilitada pela múltipla filiação (Mische, 2008), conseguiu afirmar a participação popular como dimensão importante na produção da política pública de habitação na cidade (Tatagiba e Teixeira, 2007).

No próximo ano, o CMH completará uma década de existência e hoje já podemos afirmar que, para além de uma instância formal de participação, ele figura como importante ator/cenário na rede da política. O CMH foi se consolidando como arena política relevante à medida que os atores, em suas sucessivas gestões, vivenciaram a experiência de participar e de não participar, de encaminhar suas demandas por dentro/fora ou só por fora desse canal, de estar em posição hegemônica ou minoritária e dos impactos que essas diferentes condições colocavam para a realização 
dos interesses e para o encaminhamento eficiente de suas demandas no interior dessa arena. A pesquisa mostra que o conselho vai assumindo posição importante no repertório dos atores à medida que se revela - pela experiência - uma arena capaz de aumentar os custos dos adversários e potencializar tanto as ações próprias quanto as dos aliados. Com isso, o campo de disputa em torno da direção do $\mathrm{CMH}$, inicialmente homogeneizado por um campo ético-político de esquerda articulado em torno do PT, se amplia e se complexifica pelo crescente interesse dos demais partidos - especialmente do governo paulistano e da coligação DEM, PSDB e PPS - que passam a disputá-lo.

Nesse processo, as linhas de clivagens PT versus PSDB, fortes na estruturação recente do sistema partidário brasileiro (Limongi e Cortez, 2010), repercutem de uma forma sensível também na política do $\mathrm{CMH}$, reafirmando a polarização entre esquerda e centro-direita - no caso de São Paulo com preponderância desta última. A experiência suscitada pelas sucessivas disputas e arranjos em torno do CMH - em grande medida pautadas por essa polarização - levou os participantes dos dois lados da disputa a mudar as regras eleitorais no último pleito, propiciando a institucionalização e a valorização de um arcabouço que favorece o pluralismo.

$\mathrm{O}$ estudo mostra também o protagonismo que o governo assumiu no processo de eleição dos representantes das organizações populares, facilitado por sua maior capacidade de articulação - ou melhor, de formar chapas únicas e coesas - quando comparado ao movimento. O movimento de moradia mostrou grande dificuldade de coordenar as ações do conjunto das organizações, grupos e indivíduos que o compõe. Essa dificuldade em agir coletivamente o fez sair dividido para a disputa e limitou o apoio do PT e de seus parlamentares, que preferiram evitar os custos de apoiar divisões dentro do movimento. A forma de atuação das diversas organizações do movimento para a disputa de assentos no 
conselho seguiu uma estratégia mais ou menos comum: 1 . articulação das organizações, 2. o trabalho da multiplicação de apoios, 3. divulgação incisiva das chapas e 4. vigilância intensiva no dia do pleito. Um repertório que o movimento conhece bem e que tem historicamente utilizado nas eleições executivas e legislativas no apoio aos seus candidatos.

Nessa experiência, vemos como as dinâmicas participativas bebem na fonte dos repertórios já conhecidos e se baseiam - não sem tensões e conflitos - em vínculos e lealdades já constituídas no decurso das encarniçadas disputas travadas nos territórios para as eleições executivas e legislativas. Os processos participativos se constituem a partir de pontos variados de intersecção entre pessoas organizadas pelos movimentos sociais, agentes do governo e aqueles que falam e atuam em nome de partidos e orientações partidárias. Constroem-se sobre engates e aprendizados prévios, embora no seu curso possam favorecer a emergência de novos pon178 tos de conexão - ao facultar a líderes comunitários de regiões mais pobres e distantes da cidade contato com dirigentes públicos municipais nos conselhos, e/ou projetá-los, desde a posição de conselheiros, ao interior dos quadros partidários - e/ou enfraquecer outros (como por exemplo, o contato entre esses líderes e seus aliados das comunidades de origem), assim como podem colocar em xeque a qualidade dos vínculos existentes ao ampliar os pontos de acesso ao Estado e diminuir a importância dos brokers ${ }^{1}$.

Assim, as dinâmicas participativas não se constroem no vazio; pelo contrário, deitam suas raízes nas tramas relacionais existentes e a elas se adaptam ao mesmo tempo em que podem potencialmente transformá-las.

Analisar as experiências participativas sob esse registro abre um campo teórica e empiricamente estimulante, sobre

\footnotetext{
1 Brokers são atores que conectam outros não diretamente relacionados entre si. Para uma aplicação do conceito na análise das redes de movimentos sociais remetemos a Diani (2003a).
} 
o qual, apesar dos avanços verificados nos últimos anos, ainda temos pouco acúmulo. Nesse sentido, este artigo se insere na esteira de uma nova onda de estudos sobre as inovações democráticas no Brasil, que busca reconectar à agenda da participação questões relativas aos movimentos sociais e seus repertórios de ação. Para elaborá-lo, uma pesquisa de campo com extenso levantamento documental e entrevistas semiestruturadas foi realizada entre agosto de 2009 e maio de $2010^{2}$.

Nossa exposição estrutura-se em seis partes. Inicialmente, recuperamos o debate bibliográfico sobre as inovações democráticas no Brasil, indicando a agenda de pesquisa em que nos situamos e que consideramos profícua para avançarmos. Em seguida, fazemos um voo panorâmico sobre as estratégias de ação do movimento de moradia em sua relação com os diferentes governos da capital paulista. Na terceira parte, registramos as interconexões entre as dinâmicas participativas e partidárias nas eleições para o $\mathrm{CMH}$ nos anos de 2003, 2005 e 2007. Partindo de uma análise sobre as regras do jogo eleitoral, a quarta, quinta e sexta partes debruçam-se sobre o processo e os resultados da eleição de 2009.

\section{Participação, movimentos sociais e repertórios de ação: os desafios da relação}

A bibliografia sobre a participação no Brasil avançou muito na última década. Temos hoje uma produção diversificada e qualificada que, a partir da identificação das variáveis relevantes, alia o conhecimento profundo dos casos em foco a um investimento no sentido da generalização teórica. Os métodos e estratégias de pesquisa também avançaram

\footnotetext{
2 Essa pesquisa é parte de um quadro mais amplo delineado no âmbito do projeto internacional e comparado Processus et acteurs latino-américains de la participation politique, coordenado por Camille Goirand (Institut D'Estudes Politiques de Lille). A pesquisa conta com o financiamento da Agence Nationale de la Recherche/Institut de Recherche du Développement. Também contamos com o apoio financeiro do CNPq.
} 
com uma interessante combinação das técnicas "quanti" e

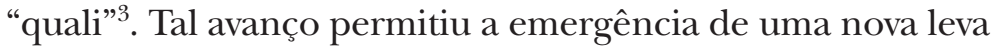
de estudos sobre as experiências de inovação participativa a partir de registros mais amplos, que remetem à sua ancoragem institucional e societal. Para isso, esses estudos mobilizam um conjunto mais diversificado de referências analíticas que, no todo ou em parte, busca lidar com os desafios da relação. Ou seja, a ênfase se desloca da análise dos desenhos institucionais e da dinâmica política interna dos espaços participativos - característica principal da produção até meados dos anos 2000 - para desenhos de pesquisa que elegem como problemas centrais a forma como esses espaços se conectam com os seus contextos mais amplos e os significados que adquirem a partir desses pontos de referências externos. Quatro coletâneas publicadas entre 2009 e 2010 oferecem bons exemplos dessas novas tendências.

No livro sobre participação e saúde no Brasil, Soraya Côr180 tes (2009) elabora um construto teórico a partir das contribuições da abordagem político-institucional e do neoinstitucionalismo histórico. Focalizando as redes formadas entre atores sociais e destes com os atores estatais, a autora demonstra como a configuração dessas relações define os papéis institucionais que os mecanismos participativos podem ter desempenhar no contexto da política de saúde. Ao invés de salientar os antagonismos na relação entre Estado e sociedade, busca-se compreender a interdependência entre os atores - envolvidos em relações de poder assimétricas -, através dos conceitos de redes de políticas e comunidades políticas.

Em uma pesquisa sobre participação na política de água no Brasil, Rebecca Abers (2010) erige como problema central a relação entre atores e instituições políticas. Nessa direção, conclui que os problemas relacionados à baixa efi3 Em Dagnino e Tatagiba (2007), apresenta-se um panorama dessa produção mais
recente. 
cácia dos comitês de bacia não residem nos organismos em si, seus membros e sua dinâmica interna,

o problema principal se encontra no contexto institucional que limita a capacidade dos colegiados de utilizarem os recursos que mobilizam. [...] As maiores limitações ao desenvolvimento de um sistema efetivo de decisão participativa se encontram na estrutura e nos recursos dos órgãos estatais que interagem com os organismos de bacia (Abers, 2010, p. 30).

O esforço de avaliação dos resultados das experiências participativas sobre seus contextos institucionais e societários se destaca na pesquisa coordenada por Leonardo Avritzer (2010). Nessa pesquisa, a preocupação com os impactos das experiências participativas - amparada no conceito de efetividade deliberativa - levou à formulação de um "Índice de Participação Municipal”. A partir de um esforço comparativo de fôlego, esse índice testou a correlação entre a existência de instituições participativas e a distribuição de recursos públicos. O estudo explora uma área ainda pouco estudada, que remete aos impactos da participação sobre o desempenho administrativo dos governos.

Partindo de um debate crítico com a agenda da sociedade civil e da participação, Isunza Vera e Gurza Lavalle (2010) buscam um giro analítico que confere centralidade às noções de controle social e representação. Com isso, visam colocar de pé temas de pesquisa que remetem aos efeitos da participação e aos mecanismos responsáveis pela produção de tais efeitos. Nesse esforço, novas ferramentas teórico-metodológicas são propostas para enfrentar o desafio de compreender as interações entre Estado e sociedade:

isto supõe uma compreensão das experiências de inovação democrática como fenômenos políticos de caráter 
relacional, dando um peso maior do que a literatura costuma dar à caracterização das relações entre os atores envolvidos nas experiências de inovação (Gurza Lavalle e Isunza Vera, 2010, p. 47).

A questão da relação entre participação e representação coloca em primeiro plano o problema da ancoragem social dos dispositivos participativos. Chamando a atenção para o fato de que as instituições participativas não são, via de regra, espaços de participação direta, mas que, nas suas arenas ampliadas de exercício do poder, acionam distintas modalidades de representação, esses estudos têm lançado nova luz sobre problemas clássicos da democracia representativa. A questão da legitimidade da representação, dos critérios para escolha dos representantes, e de quem teria direito a ser representado são temas de difícil solução prática e que têm suscitado debates teóricos relevantes (Gurza Lavalle, 182 Houtzager e Castelo, 2006 e 2006b; Gurza Lavalle e Araujo, 2006; Luchman 2007; Avritzer, 2007; Isunza Vera e Gurza Lavalle, 2010).

Como pontua de forma precisa Marcelo Kunrath e Silva (2007), nesse conjunto diversificado de estudos evidencia-se um dos desafios presentes na agenda hoje: dar um passo além da naturalização (ou essencialização) dos processos de participação que se traduz em leituras paradoxais, porque ora asseguram o caráter eminentemente democratizante desses processos, ora a tendência irrefutável no sentido da reprodução das relações hierárquicas e clientelistas. Trata-se, continua o autor, de inserir a participação na "trajetória de um espaço de relações estruturado, que define o campo das possibilidades para os resultados produzidos por tais experiências" (Silva, 2007, p. 484). Nessa mesma direção, Wampler acentua a outra ponta do processo: a necessidade de compreender as consequências da participação sobre os padrões prévios de interação entre Estado e sociedade: 
Instituições de gestão participativa estão, agora, produzindo novas redes, novos mecanismos de comprometimento sobre acordos firmados e novos tipos de conexão entre ativistas de movimentos sociais, líderes comunitários, especialistas de políticas públicas, burocratas e as prefeituras [...]. Deve haver pouca dúvida de que as interações entre Estado e sociedade civil sejam muito diferentes em 2010 do que em 1990 ou 2000 [...]. A gestão participativa contribui para inserir atores do Estado diretamente na sociedade civil, bem como líderes comunitários no Estado (Wampler, 2010, p. 395-437).

Vivemos essa "nova onda" de estudos sobre as inovações democráticas no Brasil a partir de uma chave analítica que busca agregar à agenda da participação os problemas relativos aos movimentos sociais ${ }^{4}$ e seus repertórios de ação ${ }^{5}$. Como outros autores apontaram, a partir do final dos anos de 1980, as pesquisas sobre participação, sociedade civil, espaço público e cidadania avançaram na mesma proporção em que os estudos sobre os movimentos sociais decli-

${ }^{4} \mathrm{O}$ conceito de movimento social que utilizamos apoia-se em abordagens que o associam à noção de rede, como em Melucci (1996), Della Porta e Diani (1999), Diani (2003), Diani e Bison (2010), Mische (2003, 2008). Nas formulações de Diani (2003), as redes não são encaradas apenas como recursos mobilizados pelos atores coletivos ou individuais quando estes procuram agir, mas assumem a função de instrumento analítico que permite trabalhar a dualidade entre agência e estrutura. Essa dualidade parte, basicamente, do reconhecimento de que a estrutura e a ação individual estabelecem uma relação dialética de transformação mútua.

5 O conceito de repertório de ação se inspira nas análises presentes em Tilly (1978) e Tarrow (1997). Através desse conceito, buscamos trazer para o primeiro plano os dilemas táticos e estratégicos que conformam a ação coletiva, assim como a natureza cultural dos processos pelos quais os atores definem as questões em jogo, demarcam os campos em disputa e desenvolvem processos de identificação a partir de múltiplos pertencimentos e compromissos muitas vezes contraditórios (Mische, 2008). Ao operar com o conceito de repertório, enfim, buscamos trabalhar com a ideia de que os atores dispõe de um conjunto de estratégias de ação variado, e ao mesmo tempo limitado, historicamente apreendidos e que a escolha e combinação entre estratégias de ação está condicionada pelas posições relacionais dos atores e da avaliação que fazem quanto as oportunidades de acesso ao Estado em conjunturas variadas. 
naram (Doimo, 1995; Silva [Mimeo]). Esse deslocamento temático (Gurza Lavalle, 2003) inibiu o desenvolvimento de uma agenda de pesquisa focada seja nas consequências da interação entre movimentos e atores político-institucionais para a ampliação dos direitos de cidadania, seja nas implicações da participação institucional sobre a configuração dos movimentos e suas relações com o sistema político ${ }^{6}$.

No caso brasileiro, os movimentos sociais foram fundamentais na criação e consolidação da arquitetura participativa em várias áreas de políticas públicas. Em estreita conexão com atores da arena político-institucional, tais movimentos apostaram na luta "por dentro do Estado" como estratégia de transformação social. Essa aposta gerou lutas longas e árduas que resultaram na criação e reconhecimento de novos direitos de cidadania que, por sua vez, mudaram o ambiente político no qual os governos devem operar. Tendo contribuído para a criação dessa nova arquitetura, os movimentos sociais 184 enfrentaram, nos anos seguintes, o desafio de disputar nesses novos cenários seus interesses e projetos. Para isso, modificaram suas formas de atuação, construíram novas demandas, buscaram qualificação, alteraram suas relações com a base, forjaram novos padrões de liderança, intensificaram o diálogo e os trânsitos com o campo político-institucional etc. Hoje, passadas mais de duas décadas de intensa experimentação democrática, quais os dilemas específicos que a ampliação dos canais de participação impõe à ação dos movimentos e como eles têm buscado responder a esses desafios? De que forma as estratégias de participação institucional impactam e são impactadas por esse cenário mais amplo marcado pela interconexão e fluidez entre movimentos, governos e partidos?

\footnotetext{
6 Nos últimos anos, assistimos a uma retomada dos estudos sobre movimentos sociais, mas não necessariamente a partir de uma abordagem relacional como a aqui proposta. Para uma visão sobre esses novos estudos, remetemos aos periódicos Caderno CRH (2008), Estudos Históricos (2008) e Sociedade e Estado (2006); bem como a Alonso (2009) e Silva (2010).
} 
O recente texto de Abers e Bülow (no prelo) evidencia o caráter promissor dessa nova agenda. Após apontar as insuficiências - especialmente a separação analítica entre Estado e sociedade civil - tanto da teoria do contentious politics ${ }^{7}$ quanto da literatura sobre a sociedade civil, as autoras argumentam que, para além dos espaços de participação formal, no caso brasileiro a interação entre Estado e movimentos sociais tem se dado de duas outras formas adicionais: a incorporação de militantes em cargos governamentais e a formação de novos movimentos a partir da interlocução entre ativistas dentro e fora do Estado. Como enfatizam as autoras, essas formas de relação colocam em xeque a visão do Estado como contraponto do movimento, o que demonstra a relevância não só de "teorizar sobre como os movimentos sociais constroem vínculos de colaboração com o Estado”, mas também "como às vezes movimentos sociais buscam alcançar seus objetivos trabalhando a partir de dentro do aparato estatal" (Abers e Bülow, 2011).

Estes são problemas teórica e empiricamente fecundos que emergem do encontro entre as agendas de pesquisa sobre participação, movimentos sociais e ação coletiva. A partir desse encontro, é possível avançar em outras direções para compreender a dinâmica participativa e seus resultados.

\section{Os repertórios de ação do movimento de moradia nas interações com os diferentes governos da capital}

A construção da arquitetura participativa na cidade de São Paulo mostra que a ascensão de governos de esquerda resultou em ampliação dos canais de diálogo com a sociedade (Tatagiba, 2004). Os diferentes projetos políticos dos gover-

\footnotetext{
7 A teoria do contentious politics ganha corpo com o livro Dynamics of contention, publicado por McAdam, Tarrow e Tilly em 2001. Esses autores defendem um modelo baseado no conflito político para a análise de movimentos sociais, em contraposição à abordagem clássica dominante na década de 1980, que enfatizava a reciprocidade e a comunicação (Abbers e Bulow, 2011).
} 
nos repercutiram concretamente em maior ou menor possibilidade de acesso ao Estado, impactando as estratégias de ação dos movimentos sociais. Não foi diferente no caso do movimento de moradia ${ }^{8}$.

Entre os diferentes movimentos populares existentes na cidade de São Paulo hoje, o de moradia é um dos principais ${ }^{9}$. O movimento tem um grande poder de convocação e de mobilização, em geral articulando repertórios de ação que vão das ocupações de prédios públicos à participação em espaços institucionais. É constituído por uma rede de organizações, grupos, ONGs, instituições e indivíduos com uma atuação multiescalar: partindo dos bairros, atinge os níveis municipal, estadual e nacional. Essa rede inclui pontos que a conectam com articulações internacionais pela moradia, como o Habitat International Coalition-América Latina, a Secretaria Latinoamericana Vivienda Popular, a Rede Mulher e Habitat, dentre outros. Embora forte e com considerável 186 visibilidade na cidade, é um movimento muito fragmentado internamente. Há uma intensa competição entre as organizações constitutivas da rede; e são frequentes divergências e rachas que geram novas organizações - muitas vezes com perfis similares -, tornando ingrata a tarefa de definir as fronteiras do movimento.

Uma das fontes de tensão entre as organizações do movimento é a disputa pelo acesso aos programas de moradia para população de baixa renda. Essa tensão está relacionada, por sua vez, ao papel que essas organizações desempenham (ou buscam desempenhar) na operacionalização da política habitacional. A forma como está construída a política habitacional - pulverizada numa dezena de espaços de poder - em

\footnotetext{
8 A discussão que se segue está baseada em Tatagiba (no prelo).

9 Há uma significativa produção sobre o movimento de moradia em São Paulo, principalmente sob a forma de teses e dissertações. Dentre as mais recentes, ver Santos (2010), Miagusko (2008), Neuhold (2009), Oliveira (2010), Hirata (2010), Aquino (2008).
} 
níveis federal, estadual e municipal (Cymbalista e Santoro, 2007), leva as organizações a atuarem em diferentes espaços e a partir de diferentes estratégias, acirrando, assim, as divergências e a competição entre elas. Outro aspecto comumente mobilizado pelos atores e pela bibliografia para explicar as disputas entre as organizações que integram o movimento é a divergência em relação às formas de atuação: a ocupação (ou não) de prédios e terrenos vazios como forma de luta, e as vantagens e limites do diálogo com o Estado.

Os militantes do movimento possuem histórica vinculação com o PT. Tatagiba e Paterniani (no prelo), apresentam os resultados de um survey que teve como objetivo traçar um perfil do militante do movimento de moradia. Quando perguntaram se os entrevistados eram próximos a algum partido político, $72 \%$ responderam que sim. Desses, 91,6\% afirmaram ter simpatia pelo PT e 2,8\% pelo PSDB. Outros partidos foram citados, como PCB, PP, PV, PSOL, PCdoB, PTB, todos com menos de $1 \%$ de frequência. Destaca-se o tempo de militância no PT: $41 \%$ afirmaram ser filiados ou simpatizantes há mais de 20 anos. A partidarização do movimento ficou evidente também quando as autoras perguntaram aos entrevistados quais eram os principais antagonistas do movimento. Para 31\%, os inimigos do movimento eram os partidos e governos alinhados à direita, DEM e PSDB principalmente.

No governo da petista Luiza Erundina (1989-1992), o movimento de moradia passou a atuar num cenário altamente favorável, o que não significou uma relação entre governo e movimento isenta de conflitos. A área de habitação era uma prioridade do governo, assim como o diálogo com os movimentos populares um meio de operacionalizar essa política. Nesse contexto, as formas de interação com o Estado foram alteradas, como reconhece uma liderança do movimento:

Os movimentos em outros governos eram meramente reivindicativos [...]. Sempre enxergávamos o Estado como 
inimigo a serviço da burguesia. No governo de Luiza Erundina, passamos a enxergar o Estado de uma forma diferenciada, não mais como inimigo, mas como o parceiro do movimento (Cavalcanti, 2006, p.72).

Já nos governos Maluf e Pitta (1993-2000), a resistência em negociar com os movimentos levou a intensificação das ocupações, agora não só na periferia, mas principalmente na região central da cidade, sob a bandeira do direito à moradia no centro. Só a União Estadual dos Movimentos de Moradia (UMM), principal organização articuladora do movimento, afirma ter organizado mais de trinta ocupações em prédios públicos no centro de São Paulo entre 1995 e 1999.

Com a volta do PT na gestão de Marta Suplicy (20012004), espaços para a deliberação sobre a política de habitação foram criados, e novos programas e projetos habitacionais para população de baixa renda foram implementados.

188 Com isso, abriram-se novas oportunidades de atuação para as organizações do movimento de moradia - principalmente aquelas ligadas de forma mais ou menos direta ao PT -, o que resultou em diminuição no número de ocupações. As organizações melhor posicionadas no interior da rede conseguiram relativa influência sobre as instâncias governamentais, dirigindo parte significativa dos seus recursos para a intervenção nas políticas públicas.

Em 2004, a aliança DEM-PSDB assume o governo municipal e, no ano seguinte, o estadual, o que coloca dificuldades para a atuação das organizações populares ligadas PT - ainda maioria no interior da rede - no campo institucional. O diálogo com os movimentos se daria via encontros bilaterais entre as organizações articuladoras do movimento de moradia, por um lado, e a Secretaria de Habitação e outros órgão públicos relacionados ao setor, por outro. Nesse contexto, a pressão e a mobilização sobre os governos municipal e estadual voltam a ocupar centralidade nas estratégias 
das organizações - mesmo no caso daquelas que tinham reorientado sua prática numa direção "mais propositiva" -, ao lado de uma intensificação das ações no plano federal, tendo em vista o contexto mais favorável pós-eleição de Lula.

Em resposta às mudanças nas condições de acesso ao Estado, as organizações do movimento alteraram suas formas de ação, revendo as estratégias de interação com o governo. Elas produziram cenários mais ou menos favoráveis aos seus interesses, implicando, mais uma vez, o desafio de rever formas de ação. As estratégias foram se construindo e modificando no próprio jogo relacional, a partir de uma avaliação do poder relativo de cada ator nas conjunturas específicas. Assim, a mobilização dos repertórios aparece em parte condicionada pelo contexto no qual as organizações do movimento atuam. Se a existência de uma política pública que incorpora a participação popular no processo de planejamento e implementação tende a empurrar as organizações - até mesmo as mais "radicais" - às diferentes formas de negociação com o Estado, uma política pública menos permeável à influência dos atores societais tende a empurrá-las - até mesmo as mais "propositivas" - para as diversas formas de ação direta ${ }^{10}$. Com a criação do CMH, em 2002, houve uma progressiva reconfiguração das estratégias de ação do movimento. Diante da perspectiva concreta de poder influenciar as políticas públicas para a população de baixa renda, ele passa a dirigir parte de seus recursos organizacionais para se fazer presente e interferir na direção desse conselho. É nesse contexto que se inserem as disputas em torno da eleição dos representantes populares para o CMH.

\footnotetext{
${ }^{10}$ Claro que a forma como cada organização do movimento responde a esses diferentes contextos, assim como os resultados que obtêm varia, dentre outras coisas, em função dos seus recursos organizacionais, de sua posição relativa no interior da rede, de seus projetos políticos etc. Aliás, um interessante campo de investigação a ser explorado é a forma como contextos, projetos e estratégias se combinam na produção de diferentes resultados.
} 
Visando reconstituir as regras e os resultados desse processo eleitoral (ocorrido em 2009), o nosso acompanhamento envolveu extenso levantamento documental. Para isso, utilizamos dados oficiais da prefeitura de São Paulo, documentos produzidos pelas organizações do movimento, boletins de divulgação das chapas, e análise das atas da terceira gestão do conselho (2007-2009). A "escavação virtual" na internet - principalmente blogs de parlamentares, sites dos partidos, da prefeitura e redes de comunicação dos militantes - foi também um instrumento útil para recuperar as redes de apoio em torno das chapas. Também realizamos cinco entrevistas semiestruturadas com lideranças do movimento de moradia que estavam ativamente envolvidas no processo eleitoral, além de um representante da sociedade civil no CMH. Com o apoio da equipe do Núcleo de Pesquisa em Participação, Movimentos Sociais e Ação Coletiva (Nepac), da Unicamp ${ }^{11}$, acompanhamos eventos 190 promovidos pelo movimento ${ }^{12}$. Para a análise quantitativa dos resultados da eleição, partimos de um banco de dados fornecido pela prefeitura, com uma agregação dos dados por subprefeitura.

\section{A representação das organizações populares no CMH em perspectiva comparada}

O CMH foi criado na gestão da prefeita Marta Suplicy, do PT, após forte pressão do movimento de moradia e seus aliados no campo institucional. Segundo sua lei de criação, n. 13.425

\footnotetext{
${ }^{11}$ O Nepac, coordenado pela profa. Luciana Tatagiba, iniciou suas atividades em 2008 e hoje congrega um conjunto de alunos da graduação, mestrado e doutorado em ciência política, antropologia e sociologia. Além de um espaço para discussões teóricas, o Nepac tem investido na experimentação de métodos de pesquisa tentando responder ao desafio de apreender e analisar as relações entre atores organizados em movimentos sociais, agentes do Estado, representantes e militantes partidários.

12 Agradecemos às lideranças do movimento de moradia o tempo que dedicaram ao nosso estudo e o acesso que nos facultaram aos espaços de mobilização e articulação do movimento.
} 
de 2 de setembro de 2002, o CMH é um órgão deliberativo, fiscalizador e consultivo, vinculado à Secretaria Municipal de Habitação e Desenvolvimento Urbano, e tem como objetivos básicos o estabelecimento, acompanhamento, controle e avaliação da política municipal de habitação e gestão do Fundo Municipal de Habitação (FMH), cujos recursos giravam em torno de R $\$ 44$ milhões em $2009^{13}$. Falamos, portanto, de um conselho relativamente recente na cidade de São Paulo, que no ano de 2010 iniciou sua quarta gestão ${ }^{14}$.

O CMH é uma instância de participação que aciona diferentes modalidades de representação. Ele é composto por 48 membros titulares e igual número de suplentes. $\mathrm{O}$ poder público possui um terço dos assentos e os outros dois são reservados aos conselheiros da sociedade civil: 16 representantes de entidades comunitárias e de organizações populares ligadas à habitação; e 16 de outras entidades da sociedade civil ligadas à questão habitacional, como ONGs, universidades, sindicatos etc. Os representantes do poder público são indicados pelo Poder Executivo; os das entidades da sociedade civil são eleitos por seus respectivos segmentos em fóruns próprios; e os das entidades populares ligadas à habitação são escolhidos por meio de eleições nas subprefeituras.

A eleição para escolha das organizações populares é territorializada e direta, e o único requisito para participar é possuir o título de eleitor na cidade de São Paulo. Para votar, o eleitor deve comparecer à subprefeitura da região de sua zona eleitoral, munido do título de eleitor. A eleição é coordenada pela Secretaria Municipal de Habitação através da secretaria executiva do CMH. Os editais das eleições devem ser publicados no Diário Oficial e disponibilizados no site da

\footnotetext{
${ }^{13}$ Valor definido na lei n. 14.871 de dezembro de 2008, que estima a receita e fixa a despesa do munícipio. De acordo com a lei n. 15.356 de dezembro de 2010, o valor previsto para 2011 é de $\mathrm{R} \$ 55$ milhões.

${ }^{14}$ Para uma análise mais detalhada do CMH de São Paulo, remetemos a Tatagiba e Teixeira (2007).
} 
prefeitura ao final de cada biênio, quando novas eleições são realizadas. Até a eleição para a terceira gestão do CMH ocorrida em 2007, era usado o sistema de urnas eletrônicas do Tribunal Regional Eleitoral (TRE) de São Paulo. Por uma decisão da Justiça Eleitoral em 2009, o sistema deixou de ser utilizado em eleições que não são obrigatórias. Em decorrência disso, o pleito do CMH ocorrido naquele ano usou, na denominação do próprio TRE, um Terminal Municipal de Votação Eletrônica (TMVE), ou seja, um computador comum que simula uma urna eleitoral. Como nas ocasiões anteriores, a base eleitoral foi cedida pelo TRE de São Paulo à Prodam, empresa contratada para organizar o processo ${ }^{15}$.

Na primeira eleição, realizada em 2003, participaram do pleito 31.765 eleitores; em 2009, foram 47.624, número que representa um aumento de aproximadamente $50 \%$. O significado desses números é relativo. Por um lado, se comparado com o tamanho do colégio eleitoral de São Paulo, temos um 192 comparecimento às urnas de menos de $1 \%$ dos eleitores aptos a participar, o que pode ser considerado um percentual muito pequeno. Por outro lado, sendo esta uma eleição não obrigatória, para uma instância de participação pouco conhecida e que não conta com a divulgação e os recursos envolvidos num pleito geral, os números podem ser considerados expressivos.

O perfil dos representantes populares eleitos em cada gestão do $\mathrm{CMH}$ tem variado bastante, acompanhando de certa forma as rupturas que marcam a gestão política na cidade, como indicaremos a seguir.

Conforme assinalado anteriormente, o $\mathrm{CMH}$ foi criado no governo da petista Marta Suplicy e teve sua primeira gestão entre 2003-2005. Em 2004, no meio da primeira gestão do conselho, o comando político municipal passou para as mãos de José Serra, numa coligação entre PSDB e DEM.

\footnotetext{
${ }^{15}$ Informações extraídas da ata da $10^{a}$ reunião ordinária do $\mathrm{CMH}$, de 16 de setembro de 2009.
} 
Assim, enquanto na primeira gestão do conselho a composição societária foi marcada por um alinhamento com o PT - alinhamento à esquerda -, permitindo o compartilhamento de projetos entre Executivo e sociedade civil, o período posterior se caracterizou pelo forte conflito entre os representantes das organizações populares e os técnicos do governo (Tatagiba e Teixeira, 2007). A mudança na direção da Secretaria Municipal de Habitação é emblemática. No governo petista, o secretário era Paulo Teixeira, com atuação na questão urbana e indicado ao cargo pela UMM (Cavalcanti, 2006, p.88). No governo Serra/Kassab, quem assume esse cargo é Orlando de Almeida Filho, então presidente do Sindicato da Habitação (Secovi), o maior sindicato do mercado imobiliário da América Latina. Na primeira gestão, Almeida Filho representava os sindicatos de corretores de imóveis; já na segunda, ele volta como secretário de habitação e presidente do CMH. Essas nomeações evidenciam os diferentes projetos para a área de habitação e gestão da cidade nos dois governos.

Na segunda gestão (2005-2007), o perfil dos representantes eleitos, principalmente no caso do segmento das organizações populares de moradia, mudou de forma significativa: o movimento de moradia não conseguiu eleger nenhum representante. Analisando os resultados da eleição, Tatagiba e Teixeira afirmam:

nenhuma das entidades/movimentos presentes na $1^{\mathrm{a}}$ gestão conseguiu assento no conselho na $2^{a}$ gestão. Houve uma renovação completa desse segmento, saíram movimentos mais combativos, ligados ao tema da moradia na cidade, e entram em cena associações de mulheres, clubes de mães e associações de moradores (Tatagiba e Teixeira, 2007, p.86).

Em termos partidários, constata-se uma maior vinculação dos eleitos com o PSDB. Temos, portanto, uma segunda gestão que também se caracteriza por um alinhamento polí- 
tico entre representantes do poder executivo e representantes populares, só que agora este alinhamento está à direita. Esse resultado pode ser associado ao empenho dos militantes do PSDB para elegerem seus candidatos. Nesse sentido, é muito interessante um comunicado que circulou entre militantes do PSDB convocando as pessoas a participarem da votação dos conselheiros populares apoiados pelo partido, na eleição para a segunda gestão do CMH:

O Conselho é importante pois ajuda a Prefeitura na destinação dos recursos do Fundo Municipal de Habitação. O Conselho está há muitos anos sendo "dominado" pelo PT, o que de certa forma prejudica as ações de vereadores do PSDB e consequentemente da Prefeitura. Portanto esse ano [2005] o PSDB montou uma chapa para concorrer ao Conselho, a chapa conta com integrantes de movimentos sociais pela luta por moradia, responsáveis por mutirões em suas comunidades, organizadores de mutirões da CDHU, enfim uma chapa forte e que não tem simplesmente o objetivo de derrotar "essa" ou aquela "chapa", mas sim um conjunto de pessoas que tem histórico no movimento de habitação e que querem seu espaço para continuar lutando por moradia digna para todos. [...] É preciso votar em dezesseis conselheiros, portanto vamos votar na chapa do PSDB e fortalecer a política tucana de habitação. [...] Se possível, além de ir, leve parentes e amigos pois só assim teremos condições de descentralizar o conselho das mãos do PT. Segue em anexo o nome e o número dos integrantes da Chapa do PSDB. [...] O material oficial pode ser retirado no Diretório Estadual do PSDB (TucanUSP, 2005).

É importante registrar que, embora o e-mail se refira à “chapa do PSDB", a eleição ainda era organizada em torno de candidatos. As chapas existiam apenas informalmente uma regra que, como veremos adiante, se altera na quarta 
eleição -, não obstante essas listas fossem conhecidas e frequentemente nomeadas como "chapa do governo", "chapa do movimento" etc.

Na terceira gestão do CMH (2007-2009) assistimos a mais uma mudança no perfil das organizações populares presentes no conselho. Depois de uma eleição disputada, os representantes do movimento de moradia retornam maciçamente. Em 2007, a coalizão DEM/PSDB venceu as eleições municipais numa nova disputa com o PT. O prefeito Gilberto Kassab (DEM) foi reeleito e inicialmente manteve o mesmo secretário à frente da Secretaria de Habitação. O CMH se configurou como um conselho cujos representantes populares se colocam como oposição ao Executivo. Esse resultado está muito associado ao empenho dos militantes do movimento e do PT para elegerem seus candidatos; uma postura muito diferente da verificada na eleição para a segunda gestão, quando aparentemente o campo político não se engajou na campanha para o conselho (Tatagiba e Teixeira, 2007) ${ }^{16}$. Circulou pela rede do campo um informativo e uma série de e-mails divulgando uma lista ("chapa”) de quinze candidatos para a formação de um conselho "representativo e popular", sendo que todos os nomes indicados eram de lideranças do próprio movimento de moradia. Pudemos comprovar, também através da internet, que a divulgação dessa "chapa" contou com o apoio de diversos nomes claramente identificados com o $\mathrm{PT}^{17}$. Vejamos um trecho de um desses sites petistas, depois do resultado da eleição:

\footnotetext{
${ }^{16}$ De acordo com Tatagiba e Teixeira (2007), é possível que naquele momento o movimento tenha direcionado sua mobilização para o Processo de Eleição Direta (PED) interna ao PT em detrimento da eleição do CMH, ambas marcadas para o mesmo dia.

${ }^{17}$ Tais como os blogs do deputado federal Paulo Teixeira (ex-secretário de habitação da gestão Marta Suplicy em São Paulo), "São Paulo é PT" e "blog do Favre" (militante petista); os sites dos parlamentares: vereador Paulo Fiorilo, vereador Chico Macena, deputado estadual Simão Pedro, deputado estadual Mario Reali, deputado federal José Eduardo Cardozo; e, finalmente, o boletim eletrônico da Liderança do PT na Câmara Municipal de São Paulo.
} 
As 15 candidaturas ligadas ao movimento popular foram eleitas para o Conselho Municipal de Habitação na eleição realizada no último domingo. [...] A chapa dos movimentos populares contou com o apoio do PT. O resultado vitorioso foi alcançado também porque as diversas entidades que atuam na área de moradia se uniram e compuseram uma lista única de candidatos. "Isso foi fundamental para o sucesso da eleição", observou Francisco Carvalho de Lima, o Chiquinho, membro da Executiva municipal do $\mathrm{PT} / \mathrm{SP}^{18}$.

Nesse rápido percurso histórico é perceptível o reconhecimento crescente da importância do CMH que acompanha as conquistas obtidas ou as derrotas sofridas pelos grupos nas diferentes gestões. Como assinalamos inicialmente, o $\mathrm{CMH}$ foi se legitimando como arena política à medida que permitiu aos atores ampliar seus ganhos e impingir derrotas aos seus adversários. No caso do movimento de moradia, a valori196 zação desse conselho como espaço de atuação passa por uma questão fundamental: o acesso à informação. Em várias situações de pesquisa, buscamos inquirir os líderes do movimento sobre os motivos pelos quais investiam no CMH. Afinal, é uma participação com altos custos, resultados incertos e demanda uma energia do movimento que implica deixar de lado outras ações igualmente importantes para sua sobrevivência, como a questão da formação política das bases, por exemplo. Em muitas ocasiões, ouvimos que estar no CMH é importante porque lá se tem a informação "em primeira mão". Aqui informação adquire duas dimensões: é importante para o movimento de moradia, mas também para as organizações do movimento que assumem assento como representantes. Estar no CMH é saber, antes mesmo da divulgação oficial, os editais de financiamento que serão abertos, os prédios ou

\footnotetext{
18 Trecho retirado do boletim eletrônico da Liderança do PT na Câmara Municipal de São Paulo (2007).
} 
terrenos disponibilizados para Habitação de Interesse Social (HIS), as oportunidades de financiamento etc.

Por isso - como veremos adiante -, na eleição de 2009 a participação no $\mathrm{CMH}$ se torna decisiva para muitas entidades. Elas buscam a todo custo garantir que suas lideranças sejam eleitas não apenas porque almejam incidir na política pública a partir das bandeiras do movimento, mas também e talvez principalmente - porque isso permite a cada organização auferir ganhos comparativamente maiores em relação a outras do seu próprio campo. Estar no CMH pode significar chegar à frente na competição pelos escassos recursos para a habitação popular. Também nas entrevistas em profundidade realizadas com as lideranças do movimento a importância do conselho foi reafirmada. Como a agenda das organizações está muito voltada para incidir sobre a política pública no sentido de priorizar o acesso da população de baixa renda às unidades habitacionais, a avaliação dessas lideranças é que "é mais fácil fazer isso dentro do CMH do que fora dele". Afirma-se que estar dentro desse conselho é muito importante porque permite interferir na destinação dos recursos do FMH, assim como na aprovação de medidas "mais pontuais": a continuação de mutirões autogestionários, a manutenção e ampliação de famílias beneficiárias de programas habitacionais como o Locação Social, as cartas de crédito, a reforma de prédios ociosos etc. Estar no CMH é importante, portanto, porque permite que temas que interessam ao movimento venham a ser debatidos, de modo que é possível "interferir no processo enquanto ele se dá e não quando já acabou"19.

\section{A quarta eleição: as mudanças nas regras do jogo e a montagem das chapas}

Conforme assinalado anteriormente, até a terceira gestão os processos eleitorais eram organizados em torno de cha-

${ }^{19}$ Entrevista com liderança do movimento de moradia, 05/03/2010. 
pas montadas de modo informal. Formalmente, os eleitores deveriam votar em dezesseis nomes individualmente. Para a eleição de 2009, a mudança que a Comissão Eleitoral do $\mathrm{CMH}^{20}$ propôs, e que o Pleno aprovou, foi, em primeiro lugar, reconhecer as chapas e atrelar o voto do eleitor a elas, e não mais aos candidatos que dela fazem parte. Assim, os eleitores votaram apenas no número da chapa. Em segundo lugar, atribuiu-se um caráter de proporcionalidade à eleição, com o uso do quociente eleitoral para calcular o número de cadeiras a que cada chapa teria direito ${ }^{21}$. O impacto concreto dessa mudança sobre a composição das organizações populares do CMH foi o de que este não seria mais $100 \%$ "de esquerda" ou "de direita”, como vinha acontecendo até então.

É interessante destacar que, segundo os entrevistados, a iniciativa de mudar as regras eleitorais partiu dos representantes populares que participavam da terceira gestão do 198 CMH. Uma entrevistada nos explicou que a proposta da eleição proporcional por chapa surgiu porque, ao longo das outras gestões, o movimento percebeu os efeitos negativos da composição de conselheiros populares totalmente alinhada a uma mesma força política. Essa entrevistada se referia particularmente ao fato de que, quando os conselheiros populares eram todos alinhados ao governo, o $\mathrm{CMH}$ ficava muito atrelado ao Poder Executivo, sem vozes dissonantes.

A experimentação em torno das regras eleitorais evidencia o aprendizado dos atores ao longo do processo. Tanto no caso do alinhamento à esquerda quanto do à direita, a oposição foi banida e com ela a pluralidade da representação. Os debates no interior da comissão eleitoral trouxeram à tona os problemas de um CMH do "tudo ou nada", no qual

\footnotetext{
${ }^{20}$ Essa comissão é composta por conselheiros dos três segmentos representados no CMH.

${ }^{21}$ O cálculo do quociente eleitoral é feito de acordo com as instruções do TRE.
} 
quem vence leva tudo e quem perde está completamente fora. A proposição das mudanças, no entanto, não aconteceu sem dificuldades e divergências para e no movimento de moradia. Enquanto a comissão eleitoral buscava chegar a uma proposta definitiva, reuniões eram feitas pelo movimento para tentar formular consensos em relação às mudanças.

Um dos desafios nessa eleição foi justamente a montagem das chapas. No caso do movimento popular isso foi especialmente difícil. Com a decisão final da comissão eleitoral, as disputas no interior do movimento passaram a girar em torno do número de chapas do movimento e dos nomes que ocupariam as primeiras posições da lista de candidatos. Se no processo eleitoral anterior o movimento conseguiu se articular em torno de uma única chapa, em 2009 ele disputou o CMH rachado em três chapas concorrentes ${ }^{22}$.

Além dessas três chapas do movimento, havia uma quarta chapa chamada "Habitação no Rumo Certo", identificada pelos entrevistados como sendo a "chapa do governo", ou seja, formada por candidatos das organizações populares alinhadas aos partidos da coalizão governista (PSDB, DEM e PPS). O nome da chapa se inspirou no slogan "São Paulo no Rumo Certo", usado na campanha de Gilberto Kassab (DEM) à prefeitura de São Paulo em 2008. Esta foi a única chapa que indicou dezesseis candidatos, o máximo possível. É interessante ressaltar que a divulgação das chapas no site da prefeitura indica apenas os nomes dos candidatos, não as organizações que eles representam. Essa característica permite aos nossos entrevistados identificar o que chamam de "chapa do governo", menção comum em todas as entrevistas. Perguntamos como eles associam determinadas pessoas ao governo:

\footnotetext{
22 São as chapas associadas a três organizações articuladoras do movimento: a UMM, a Frente de Luta por Moradia (FLM) e a Confederação Nacional das Associações de Moradores (Conam).
} 
A gente conhece as pessoas, elas são tradicionalmente mais filiadas ao PSDB ou ao "DEMO" [DEM] do que propriamente representante do movimento. E eles falam no discurso: "nós somos base de sustentação do governo Serra, nós somos base de sustentação do governo Kassab"23

A quinta chapa da disputa é formada por apenas um titular e um suplente; é identificada pelos atores como sendo uma chapa "independente". Portanto, mudadas as regras do jogo eleitoral no $\mathrm{CMH}$, cinco chapas se apresentam para a disputa.

\section{A campanha de divulgação das chapas e 0 dia da eleição}

Depois de montadas as chapas, o trabalho das lideranças do movimento de moradia foi tomado pelas atividades de campanha, que consistiam, basicamente, em rodar pela cidade

200 inteira para entrar em contato com seus potenciais eleitores. Trata-se de um "trabalho de multiplicação".

Eu acho que é um trabalho de multiplicação. Então a gente trabalha na nossa base a questão do Conselho e cada um é responsável por trazer "x" eleitores [...]. Tem isso, tem o trabalho de ir pra base e discutir, de seguir pra favela, como se fosse uma eleição de vereador. Cada um trabalha e fica responsável no seu núcleo. Por exemplo, seu núcleo é de mil pessoas, então cada um era responsável por trazer dez. ${ }^{24}$

É muito interessante notar a relação que a entrevistada estabeleceu entre a eleição do CMH e a de vereador. Isso porque as lideranças do movimento de moradia costumam se engajar nas campanhas eleitorais tanto para a Câmara Muni-

${ }^{23}$ Entrevista com liderança do movimento de moradia, 04/11/2009.

${ }^{24}$ Entrevista com liderança do movimento de moradia, 05/03/2010. 
pal quanto para a prefeitura da cidade, normalmente a favor dos candidatos do PT (Cavalcanti, 2006). Assim como nas eleições para vereador, a tática consiste em mobilizar os territórios de abrangência de cada uma das lideranças. Elas mobilizam seus "coordenadores", que possuem contato com a base - formada pelos chamados grupos de origem - de cada organização nas regiões da cidade (lembrando que o movimento de moradia se organiza territorialmente). Amanda Hornhardt ${ }^{25}$ acompanhou o trabalho de divulgação de uma das chapas em um prédio ocupado por uma das organizações do movimento e registrou em seu diário de campo em 02/10/2009:

A liderança [do movimento de moradia] entregou o panfleto para o morador dizendo: "não vai esquecer que dia 4 é a eleição para o Conselho Municipal de Habitação, vai lá votar pra gente continuar conseguindo casa pros nossos irmãozinhos que ainda não conseguiram". Ele disse que não ia poder votar, porque teria que trabalhar no domingo, mas que ia tentar arranjar algum voto para substituí-lo,"o prédio inteiro vai votar por mim”, disse. Daí a [liderança] começou a falar da importância que tem um voto... Em um dos apartamentos que passamos uma mulher pergunta para a liderança: "quantos votos eu preciso conseguir além do meu?” A liderança explicou que alguns grupos usavam esta estratégia de que cada pessoa teria que conseguir mais nove votos, por exemplo. Ela disse que não trabalha com esta estratégia, apenas conversa com o morador que atender, pede o voto, pergunta quantas pessoas que votam moram ali e deixa os folhetos. A liderança também perguntava onde a pessoa votava normalmente. Se a pessoa dissesse o nome de algum colégio ou rua da região

${ }^{25}$ Graduanda em ciências sociais na Unicamp e membro do Grupo de Pesquisa desde 2008. Realiza pesquisa de iniciação científica sobre a relação do PT com as organizações do movimento de moradia no governo de Luiza Erundina. 
central, ela dizia "então você vai votar aqui, na Rua Álvares Penteado..." mostrando no panfleto. Ela deixava claro a todos que a subprefeitura havia mudado de endereço e a votação seria realizada no endereço novo. Caso a pessoa falasse outro lugar fora do centro, ela anotava no verso do folheto o telefone da secretaria da UMM e pedia para a pessoa ligar lá confirmando o local de votação. Ela disse que a secretaria estaria de plantão sábado e domingo para atender as ligações e tirar as dúvidas. Ela pedia também para as pessoas levarem o título de eleitor e o R.G. no dia da votação. Assim ela ia, de porta em porta. Uma militante que a acompanhava diz, em tom de denúncia, que o zelador do prédio está participando da "Chapa do Governo".

Os militantes procuram também pessoas do seu círculo próximo para pedir a intermediação junto a potenciais eleitores e formadores de opinião. Podem ser contatos com 202 padres da igreja católica ou pastores evangélicos - que possuem afinidade com a organização -, lideranças de associações de bairro, sindicatos, ONGs, universidades e vereadores. Uma de nossas entrevistadas explica como funciona o apoio das universidades e de ONGs:

Por exemplo, no Instituto Pólis a gente fez um seminário pra várias pessoas. [O Pólis dizia:] "venham candidatos de vocês, tragam o material e vamos fazer uma discussão". A PUC [...] cedia o horário de aula que eles tinham, então falavam "vão lá, vai alguém e faz o debate sobre o Conselho, sobre a mudança do Conselho e automaticamente faz a campanha da chapa"26.

Quanto à participação dos partidos e do governo nessa campanha, vimos que, ao contrário da eleição de 2007, o apoio do PT a uma chapa ou não existiu ou não foi aberto.

${ }^{26}$ Entrevista com liderança do movimento de moradia, 05/03/2010. 
As explicações para essa mudança na postura do partido podem estar vinculadas a dois fatores. O primeiro reside no fato de que seria complicado para qualquer parlamentar do PT apoiar abertamente uma chapa do movimento em detrimento de outra. Mesmo sendo sabido que certos parlamentares têm proximidade maior com uma ou outra organização, não parecia ser o caso de oficializar essa preferência. Nessa situação, o apoio a uma chapa significaria prejuízo à outra, o que certamente só contribuiria para aumentar o nível das tensões dentro do campo. Alguns sites de parlamentares petistas anunciaram data e informações importantes para as pessoas poderem votar nos candidatos, sem, no entanto, apoiar nenhuma chapa especificamente ${ }^{27}$. Outra explicação está relacionada à percepção de que nos últimos anos teria se acentuado uma tendência de distanciamento dos parlamentares do PT em relação aos temas da reforma urbana e do direito à cidade.

O governo, por outro lado, atuou ativamente na campanha, como indica a presença de material da "chapa do governo" em diversos espaços públicos municipais - subprefeituras, centros de saúde e espaços de circulação -, além do transporte de eleitores em ônibus escolares da rede pública municipal. Segundo as lideranças entrevistadas, essa teria sido a primeira vez que a "máquina pública" atuou de forma tão ostensiva. Além da forte campanha, fala-se em fraude eleitoral da parte do governo. Vejamos o que diz uma nota pública em relação ao processo eleitoral:

Foi flagrado no dia das eleições total falta de privacidade nos espaços de votação, pessoas que iam votar e seu voto já havia sido contabilizado na urna eletrônica, transporte maciço de eleitores pela chapa 2 ["chapa do governo"], grande tumulto e falta de organização, filas intermináveis

${ }^{27}$ Uma reportagem com esse intuito foi elaborada pelo PT (2009). 
com total desrespeito aos eleitores, e ainda, a presença de farto material da chapa 2 em espaços públicos, como na subprefeitura de São Mateus, desacatando de forma acintosa a orientação dada pela Comissão Eleitoral que pediu a retirada de tais materiais destes locais ${ }^{28}$.

Há na internet um vídeo com imagens e entrevistas com eleitores na subprefeitura de M'Boi Mirim no dia da eleição. A gravação mostra longas filas para votar, ônibus escolares municipais no local e pessoas que não sabiam ao certo em que estavam votando, indicando haver mobilização de eleitores por meio de práticas clientelistas ${ }^{29}$. Como veremos adiante - no item referente aos resultados da eleição -, foi justamente nessa subprefeitura que a "chapa do governo" obteve mais votos. Essa região é um conhecido reduto do vereador Milton Leite, do DEM, que teria atuado na agregação de votos para a chapa governista. Não encontramos em 204 sites e blogs do PSDB e do DEM menções à "chapa do governo" nesta última eleição. A defesa ficou por conta do $\mathrm{PPS}^{30}$, que em seu site oficial postou a seguinte nota:

No próximo dia 4 de outubro haverá eleição para o Conselho Municipal de Habitação. [...] Existem cinco chapas na disputa. Três chapas são controladas politicamente pelo PT, o que por si só parece ruim para a cidade e para a Habitação. Mas a divisão petista indica uma boa chance para a Chapa 2 - "Habitação no Rumo Certo", que tem o apoio do PPS, por meio do líder do partido na Câmara Municipal, vereador Claudio Fonseca.

\footnotetext{
28 A nota foi redigida pela União dos Movimentos de Moradia (UMM). Para mais detalhes, ver UMM (2009)

${ }^{29} \mathrm{O}$ vídeo foi realizado pelo Movimento pelo Direito à Moradia (MDM). Para mais detalhes, ver MDM (2009).

${ }^{30}$ Partido que fez parte da coligação junto com o PSDB e o DEM na última eleição para o governo do Estado de São Paulo.
} 
Mais informações sobre a eleição do Conselho Municipal da Habitação podem ser obtidas no site da prefeitura de São Paulo. Também é possível consultar aqui, com o número do título de eleitor, o local de votação (PPS, 2009).

Além do trabalho de multiplicação da fase de campanha, as lideranças do movimento de moradia se organizam para atuar no dia da eleição. Nesse momento, a mobilização das lideranças é importantíssima para garantir que o resultado lhes seja favorável. De nada adiantaria fazer campanha por toda a cidade antes do pleito, se no dia deste as lideranças não estiverem presentes nos espaços de votação para garantir que tudo corra bem. A estratégia de atuação do movimento é a do "chegar chegando", que consiste em impedir que funcionários da prefeitura ou apoiadores da "chapa do governo" tenham oportunidade de interferir na escolha do eleitor. Como nos relatou uma liderança do movimento, a grande preocupação é garantir os votos, porque nosso povo é muito simples. Para impedir a interferência de apoiadores da "chapa do governo", o movimento tem a preocupação de escolher pessoas habilidosas - conhecidas como fiscais - como nos explica uma entrevistada:

Nós conseguimos colocar dois fiscais em cada uma [das subprefeituras da Zona Norte]. Mas fiscais muito bem-preparados. Iam pra cima. Quando os funcionários [da prefeitura] falavam com algum votante eles diziam "tá falando o que aî?!”, entendeu? Duro, firme. Aqui na Zona Norte, se você verificar o mapa, eles não conseguiram roubar. Nós ganhamos aqui, porque nós não demos espaço pra que eles roubassem ${ }^{31}$.

A mobilização para a eleição do CMH, portanto, envolve muitos esforços por parte das organizações do movimen-

${ }^{31}$ Entrevista com liderança do movimento de moradia, 04/11/2009. 
to. Esse processo começa na tentativa de articulação entre as organizações, passa pela divulgação das chapas (trabalho de multiplicação) na fase de campanha e pela prática do chegar chegando do dia da eleição.

\section{0 resultado da eleição: avaliando perdas e ganhos}

O número total de eleitores na eleição dos conselheiros representantes das entidades populares para a $4^{\mathrm{a}}$ gestão do CMH foi de 47.624, o que representa o maior número de eleitores desde a criação desse conselho. Os votos foram assim distribuídos (ver Tabela 1):

\section{Tabela 1}

Distribuição dos votos na eleição dos conselheiros das organizações populares para a quarta gestão no CMH (eleição 2009)

\begin{tabular}{|c|c|c|c|}
\hline Respostas & Total de votos & $\begin{array}{c}\text { Porcentagem } \\
\text { dos votos }\end{array}$ & $\begin{array}{c}\text { N. candidatos } \\
\text { eleitos }\end{array}$ \\
\hline Chapa do governo & 28968 & 60,8 & 10 \\
\hline $\begin{array}{c}\text { Habitação no Rumo } \\
\text { Certo (Chapa 2) }\end{array}$ & 28968 & 60,8 & 10 \\
\hline $\begin{array}{c}\text { Chapas do } \\
\text { movimento }\end{array}$ & 18052 & 37,9 & 2 \\
\hline $\begin{array}{c}\text { Unidade pelo Direito à } \\
\text { Moradia (Chapa 1) }\end{array}$ & 5117 & 10,74 & 4 \\
\hline $\begin{array}{c}\text { União (Chapa 4) } \\
\text { Em Defesa do Direito à } \\
\text { Moradia (Chapa 5) }\end{array}$ & 10057 & 21,12 & 0 \\
\hline Chapa independente & 2578 & 6,04 & 0 \\
\hline $\begin{array}{c}\text { Comunitária e Cidadania } \\
\text { Consciente (Chapa 3) }\end{array}$ & 251 & 0,5 & 16 \\
\hline Brancos & 121 & 0,5 & - \\
\hline Nulos & 232 & 0,3 & 0,5 \\
\hline Total & 47624 & 100 & 0 \\
\hline
\end{tabular}

Fonte: Elaboração própria a partir dos dados oficiais da eleição. 
Como vemos na Tabela 1, a "Chapa do Governo" conquistou $60 \%$ dos votos, enquanto as três chapas do movimento juntas conquistaram apenas 37,9\%. Em termos gerais, o resultado dessa última eleição representa uma vitória para o governo e os partidos governistas, já que os candidatos por eles apoiados passaram a ocupar 10 do total de 16 cadeiras reservadas às organizações populares dentro do CMH. Esse resultado indica também uma diferença em relação às composições anteriores desse conselho. Não se trata mais de uma gestão "tudo ou nada", ou seja, onde a representatividade dos segmentos populares é homogênea - formada por um conjunto de conselheiros vinculados ao mesmo alinhamento político -, como acontecia quando o voto não era proporcional. Agora temos uma composição mais plural do segmento popular, embora com uma maioria alinhada ao governo ${ }^{32}$.

Para além dos dados gerais da votação, a distribuição geográfica dos votos também nos traz algumas pistas a serem aprofundadas em pesquisas futuras ${ }^{33}$ (ver o Gráfico 1).

A primeira informação que o Gráfico 1 nos traz é a larga vantagem da Chapa 2 ("chapa do governo") em relação às outras chapas juntas. Em primeiro lugar, ela foi a mais votada em 20 das 31 subprefeituras da cidade. Em segundo lugar, enquanto nenhuma das outras chapas bateu a casa dos mil votos nas subprefeituras, a Chapa 2 ultrapassou esse limite em 13 delas, sendo que em 3 ultrapassou os 2 mil votos e em uma chegou próxima dos 3,5 mil. Percebemos também que em algumas subprefeituras nenhuma das chapas conseguiu ultrapassar a barreira dos quinhentos votos, ou seja, são locais em que a mobilização para a eleição do

\footnotetext{
${ }^{32}$ Nessas pesquisas futuras seria interessante observar se e como essa heterogeneidade afeta a dinâmica de funcionamento do conselho, inclusive no que se refere às possibilidades de um diálogo efetivo.

${ }^{33}$ Para que o gráfico possa ser adequadamente visualizado, disponibilizamos apenas os dados referentes às três chapas que conseguiram eleger representantes.
} 
Gráfico 1

Distribuição dos votos por subprefeitura da eleição dos representantes populares*

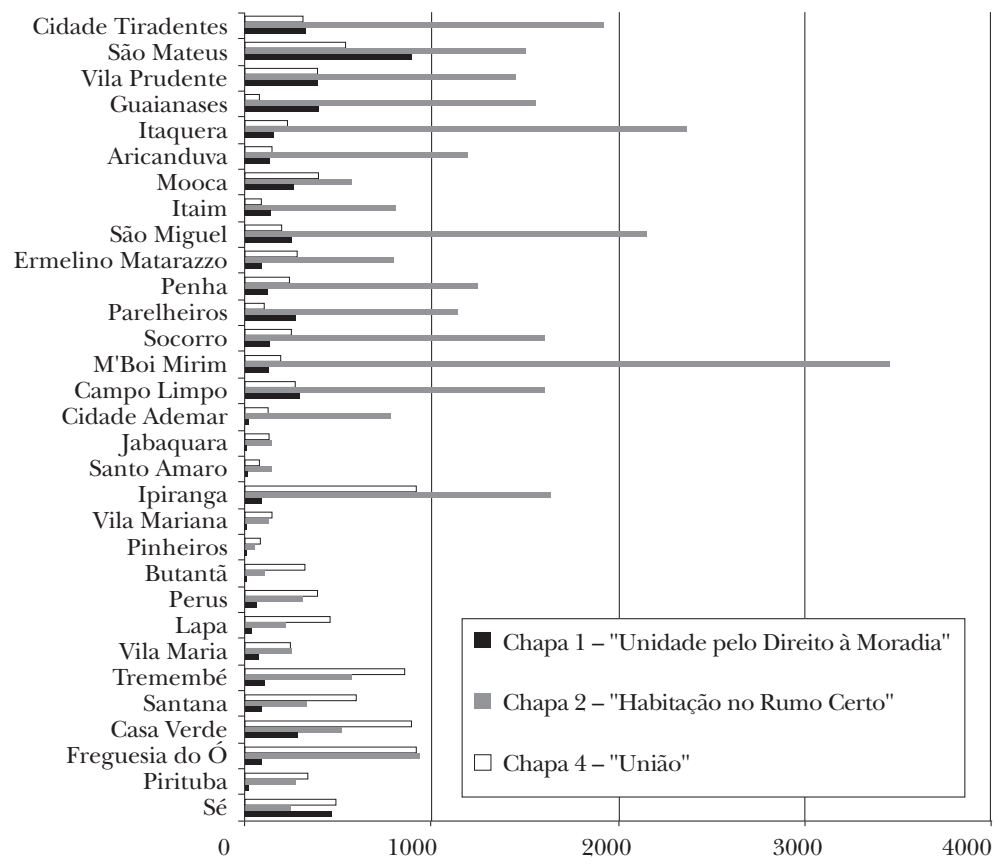

Fonte: Elaboração própria a partir de documentos.

*Apenas das três chapas que elegeram representantes no CMH.

CMH é bastante pequena ${ }^{34}$. Das 10 subprefeituras onde houve pouca mobilização, 7 delas compõe a lista de subprefeituras com o menor número de famílias que vivem com menos de meio salário mínimo (Nossa São Paulo, 2007). Ou seja, vemos que a mobilização em torno da eleição dos representantes populares do $\mathrm{CMH}$ foi muito maior nas regiões mais pobres da cidade $^{35}$. O Gráfico 1 mostra a força e o desempe-

\footnotetext{
${ }^{34}$ São eles: Jabaquara, Santo Amaro, Vila Mariana, Pinheiros, Butantã, Perus, Lapa, Vila Maria, Pirituba e Sé.

${ }^{35}$ Com exceção das subprefeituras de Perus e Pirituba, que, apesar dos altos índices de pobreza, tiveram poucos eleitores.
} 
nho diferenciado das duas chapas que elegeram candidatos do movimento de moradia nas subprefeituras. Vejamos, de um lado, o contraste entre o forte desempenho da Chapa 4 ("União") no Ipiranga e na Freguesia do Ó, e a baixa votação da Chapa 1 ("Unidade pelo Direito à Moradia") nessas regiões; e, de outro, o contraste entre o forte desempenho da Chapa 1 em Guaianases e a baixa votação da Chapa 4 nessa subprefeitura. Esses contrastes evidenciam a heterogeneidade interna do movimento.

Outros aspectos que nos chamam a atenção podem ser melhor visualizados a partir da agregação das subprefeituras em regiões da cidade (ver o Gráfico 2).

\section{Gráfico 2}

Distribuição dos votos válidos por região da cidade*

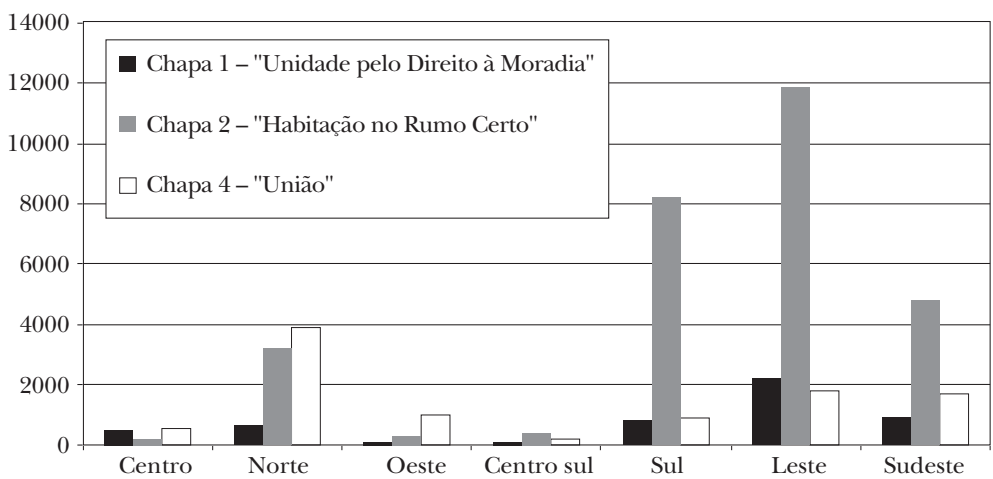

Fonte: Elaboração própria a partir de documentos.

*Apenas das três chapas que elegeram representantes no CMH.

A chapa apoiada pelo governo foi a grande vencedora na Zona Leste ${ }^{36}$, o que nos parece surpreendente. Essa região da cidade é tradicionalmente associada às mobilizações populares - como de saúde e de moradia - iniciadas na

\footnotetext{
${ }^{36}$ A zona leste é formada pelas subprefeituras de Cidade Tiradentes, São Mateus,
} Guaianases, Itaquera, Itaim Paulista, São Miguel Paulista, Ermelino Matarazzo e Penha. 
década de 1980, que se organizavam em torno das Comunidades Eclesiais de Base (CEBs), das pastorais da igreja católica e contavam com o apoio do PT. As ocupações de terras nessa região são vistas, inclusive, como o marco de origem do movimento de moradia (Gohn, 1991). Além disso, ao menos durante a década de 1990, as regiões mais pobres eram as que mais votavam nos candidatos do PT, sendo a leste o reduto eleitoral mais importante do partido (Figueiredo et al., 2002) ${ }^{37}$.

Além de examinar a distribuição dos votos por subprefeitura, analisamos a influência dos partidos no resultado da eleição do CMH, já que a pesquisa qualitativa trouxe evidências de que eles seriam importantes atores nesse processo $^{38}$. Não encontramos evidências de que o apoio dos partidos (PT ou coalizão PSDB-DEM-PPS) tenha significado melhor desempenho para as respectivas chapas em termos de votos. Por outro lado, vimos que há alguma correlação 210 entre os votos do vereador numa subprefeitura e os obtidos pela chapa apoiada por ele na mesma localidade. Assim sendo, os resultados indicam que a interferência sobre a eleição do CMH acontece através da atuação individual de alguns parlamentares - que mobilizam seus redutos eleitorais já consagrados - e não pela incidência das coalizões partidárias em geral.

\footnotetext{
${ }^{37}$ Mesmo que considerássemos a hipótese de que as bases sociais na cidade estejam passando por uma fase de reorganização desfavorável aos setores mais progressistas, os dados da eleição para vereador na cidade, em 2008, indicam que o PT ainda é muito forte na região leste.

${ }^{38}$ Agradecemos à colaboração de Márcio Caparroz, doutorando em demografia na Unicamp, que nos auxiliou com as análises estatísticas. Agradecemos também Lara Mesquita, pesquisadora do Centro de Estudos da Metrópole (CEM) e do Centro Brasileiro de Análise e Planejamento (Cebrap) por gentilmente disponibilizar o banco de dados eleitorais mantido por essas instituições. Não detalharemos aqui essa análise, que será recuperada em um próximo artigo mais focado na relação do movimento com os partidos políticos.
} 
Esse estudo sobre a eleição dos representantes das organizações populares para o CMH de São Paulo reforça uma tendência em curso na agenda de pesquisa sobre a participação: analisar as experiências de inovação democrática, mas não como o avesso dos repertórios políticos tradicionais ou sua face redentora. As dinâmicas participativas ganham vida em cenários institucionais e societários nos quais atores de carne, ossos e interesses buscam realizar seus objetivos particulares, corporativos e políticos no sentido mais estrito do termo. Os espaços de participação têm os seus limites e suas potencialidades configurados pelas tramas relacionais previamente existentes nas quais estão inscritos. Nesse sentido, a atuação dos partidos e dos governos nas eleições para o CMH não é visto aqui como anomalia ou como uma interferência perversa numa dinâmica participativa encapsulada e protegida dos efeitos nefastos do seu entorno. A participação se constrói por essas relações e a expectativa é que possa também impactá-las. Justamente nessa expectativa repousa o sentido normativo da análise aqui desenvolvida.

A presença dos partidos e o engajamento dos governos na eleição do CMH é, por um lado, resultado da atuação dos atores em redes parcialmente sobrepostas - para usar os termos de Mische (2008, p.22) - principalmente no movimento de moradia e no PT, e, por outro, da importância que esse conselho assumiu no jogo político da cidade e nas estratégias dos atores. Não é o caso de generalizar esses achados empíricos, que podem estar relacionados ao peso político da cidade de São Paulo e/ou ao montante de recursos envolvidos nessa política pública específica. De qualquer forma, chamamos a atenção para o fato de que o CMH foi se construindo como arena política relevante ao longo das suas quatro gestões, ou seja, à medida que os atores experimentaram estar dentro ou fora dele e o que isso representava para o encaminhamento de seus interesses. Foi o papel progressivamente assumido pelo CMH que fez dessa eleição um caso tão interessante e, talvez, singular. 
A eleição do CMH explicitou oposições e alianças que cruzam partido, movimento e Estado, revelando a complexidade e a heterogeneidade interna desses campos e o trânsito dos atores entre eles num sentido já anunciado por Dagnino, Olvera e Panfichi (2006). Na ânsia de influenciar os resultados da eleição, esses atores mobilizaram um repertório que já conheciam. Como explicou a militante do movimento: "era como se fosse numa eleição para vereador".

No final de 2011, haverá nova eleição para o CMH e resta saber se a posição minoritária do movimento de moradia levará a novas reflexões sobre a necessidade de criar mecanismos de coordenação e articulação internas que permitam a suspensão das divergências entre suas organizações e se ele efetivamente conseguirá reverter energias para figurar na disputa como ator coletivo coeso. Também será interessante acompanhar se (e como) governo e partidos continuaram empenhando recursos para a eleger seus aliados e quais as 212 repercussões dessas estratégias sobre a política de habitação voltada ao atendimento da população de baixa renda.

Como buscamos argumentar ao longo deste artigo, compreender as dinâmicas participativas a partir da descrição e análise das relações entre atores sociais e políticos institucionais pode oferecer novas chaves para avaliação dessas experiências e dos seus resultados. Particularmente importante seria avançar na compreensão do papel dos partidos e da militância partidária nesse cenário, um tema que, apesar de constante nos estudos de caso, ainda permanece pouco abordado de forma sistemática pela literatura da participação. Sabemos que muitas conquistas dos setores progressistas se deveram à articulação entre militantes dos movimentos e militantes partidários - papéis muitas vezes combinados num mesmo ator -, que favoreceu os fluxos de comunicação e de trânsito entre as sociedades civil e política. Mas não se trata agora de inverter completamente a chave e supor que todo tipo de vínculo entre movimentos sociais, 
partido e Estado contribuirá para o avanço de uma agenda de esquerda, o fortalecimento dos movimentos ou o aprofundamento da democracia. Tampouco que, se contribuir, o fará da mesma forma e direção. Como sugere Mische, trata-se de compreender

De que maneiras a experiência de se movimentar entre redes parcialmente sobrepostas contribui para gerar tensões e pressões, de um lado, ou inovações e autonomia, de outro? Como essas intersecções influenciam as escolhas e as ações dos indivíduos, assim como das várias coletividades às quais eles pertencem? (Mische, 2008, p. 22).

Tomar a relação entre movimentos e sistema político como questão empírica e teórica a ser enfrentada significa reconhecer o espaço próprio que conforma e condiciona os esforços despendidos nos processos de interação. Partindo do pressuposto de que a natureza e a intensidade das relações entre movimentos sociais e atores políticos são diversas - assim como o tipo e o alcance de suas implicações -, imaginamos que no longo prazo um dos resultados desses investimentos poderia ser algo como uma "tipologia dos vínculos" entre movimentos sociais e atores político-institucionais. Essa tipologia talvez fosse capaz de conferir certa inteligibilidade a essas variações relacionais, problematizando suas consequências no que se refere à escolha e combinação dos repertórios de ação em conjunturas específicas. Mas, até lá, temos ainda um longo caminho pela frente.

\section{Luciana Tatagiba}

é professora do Departamento de Ciência Política da Unicamp.

\section{Karin Blikstad}

é mestranda em ciência política pela Unicamp. 


\section{Referências bibliográficas}

ABERS, R. (org.). 2010. Água e política: atores, instituições e poder nos organismos colegiados de bacia hidrográfica no Brasil. São Paulo: Annablume.

ABERS, R.; BÜLOW, M. [No prelo]. "Movimentos sociais na teoria e na prática: como estudar o ativismo através da fronteira entre Estado e sociedade?" Sociologias.

ALONSO, A. 2009. "As teorias dos movimentos sociais: um balanço do debate”. Lua Nova, n.76, pp.49-86.

AQUINO, C.A.F. 2008. A coletivização como processo de construção de um movimento de moradia: uma etnografia do Movimento Sem-Teto do Centro (MSTC). Dissertação de mestrado. São Paulo: FFLCH-USP

AVRITZER, L. 2007. "Sociedade civil, instituições participativas e representação: da autorização à legitimidade da ação”. Dados, v.3, n.50, pp. 443-464.

. (org.). 2010. A dinâmica da participação local no Brasil. São Paulo: Cortez.

CADERNOS CRH. 2008. Salvador: CRH-UFBA, v. 21, n. 54.

CAVALCANTI, G. C. 2006. Uma concessão ao passado: trajetórias da União dos Movimentos de Moradia de São Paulo. Dissertação de mestrado. São Paulo: FFLCH-USP.

CÔRTES, S. V. (org.). 2009. Participação e saúde no Brasil. Rio de Janeiro: Ed. da Fiocruz.

CYMBALISTA, R., SANTORO, P. F. 2007. "Habitação: avaliação da política municipal 2005-2006”. In: SANTORO, P.F.; CYMBALISTA, R.; TATAGIBA, L. e TEIXEIRA, A.C. Habitação: controle social e política pública. São Paulo: Instituto Pólis.

DAGNINO, E.; OLVERA, A.; PANFICHI, A. 2006. "Para uma outra leitura da disputa pela construção democrática na América Latina”. In: DAGNINO, E.; OLVERA, A.; PANFICHI. A disputa pela construção democrática na América Latina. São Paulo; Campinas: Paz e Terra; Ed. da Unicamp.

; TATAGIBA, L. (orgs). 2007. Democracia, sociedade civile participação. Chapecó: Argos.

DELLA PORTA, D.; DIANI, M. 1999. Social movements: an introduction. Oxford: Basil Blackwell.

DIANI, M. 2003. "Network and social movements: a research programme" In: .; MCADAM, D. (orgs.). Social movements and networks: relational approaches to collective action. Oxford: Oxford University Press.

DIANI, M. 2003a. “'Leaders' or 'brokers'? Positions and influence in social movement networks" In: .; MCADAM, D. (orgs.). Social movements 
and networks: relational approaches to collective action. Oxford: Oxford University Press.

; BISON, I. 2010. "Organizações, coalizões e movimentos”. Revista Brasileira de Ciência Politica, n.3, pp. 219-250.

DOIMO, A. M. 1995. A vez e a voz do popular: movimentos sociais e participação política no Brasil pós-70. Rio de Janeiro: Relume-Dumará. ESTUDOS HISTÓRICOS. 2008. Rio de Janeiro: CPDOC-FGV, v. 22, n.42. FIGUEIREDO, A.; LIMONGI, F.; FERREIRA, M.P.; SILVA, P.H. 2002.

"Partidos e distribuição espacial dos votos na cidade de São Paulo 19942000”. Novos Estudos, n.64, pp. 153-160.

GOHN, M. 1991. Movimentos sociais e lutas pela moradia. São Paulo: Loyola.

GURZA LAVALLE, A. 2003. "Sem pena nem glória: o debate sobre a sociedade civil nos anos 1990”. Novos Estudos, n.66, p. 91-109.

; HOUTZAGER, P. P.; CASTELO, G. 2006. "Representação política e organizações civis: novas instancias de mediação e os desafios da legitimidade”. Revista Brasileira de Ciências Sociais, v. 21, n. 60, p. 43-66. 2006b. "Democracia, pluralização da representação e sociedade civil”. Lua Nova, v.67, n.67, pp.49-103.

.; ARAUJO, C. 2006. "O futuro da representação: nota introdutória”. Lua Nova, n. 67, pp. 9-14.

GURZA LAVALLE, A.; ISUNZA VERA, E. 2010. "Precisiones conceptuales para el debate contemporáneo sobre la innovación democrática”. In: (orgs.). La innovación democrática en América Latina: tramas y nudos de la representación, la participación y el control social. México: Centro de Investigaciones y Estudios Superiores en Antropología Social - Universidad Veracruzana.

HIRATA, F. 2010. A luta pela moradia em São Paulo. Dissertação de mestrado. Campinas: IFCH-Unicamp.

ISUNZA VERA, E., GURZA LAVALLE, A. (orgs). 2010. La innovación democrática en América Latina: tramas y nudos de la representación, la participación y el control social. México: Centro de Investigaciones y Estudios Superiores en Antropología Social - Universidad Veracruzana.

LIMONGI, F., CORTEZ, R. 2010. "As eleições de 2010 e o quadro partidário”. Novos Estudos, n. 88, pp. 21-37.

LÜCHMANN, L. 2007. "A representação no interior das experiências de participação”. Lua Nova, n.70, pp. 139-170.

MELUCCI, A. 1996. Challenging codes: collective action in the information age. Cambridge: Cambridge University Press.

MIAGUSKO, E. 2008. Movimentos de moradia e sem-teto em São Paulo: experiências no contexto do desmanche. Tese de doutorado. São Paulo: FFLCH-USP. 
MISCHE, A. 2003. "Cross-talk in movements: reconceiving the culturenetwork link". In: DIANI, M.; MCADAM, D. Social movements and networks: relational approach to collective action. Oxford: Oxford University Press.

MISCHE, A. 2008. Partisan publics. New Jersey: Princeton University Press.

NEUHOLD, R. R. 2009. Os movimentos de moradia e sem-teto e as ocupações de móveis ociosos: a luta por políticas públicas habitacionais na área central da cidade de São Paulo. Dissertação de mestrado. São Paulo: FFLCH-USP.

OLIVEIRA, N. C. 2010. Os movimentos dos sem-teto da Grande São Paulo (1995-2009). Dissertação de mestrado. São Paulo: IFCH-Unicamp.

SANTOS, A. L. T. dos. 2010. A prática dos movimentos de moradia na produção do espaço da cidade de São Paulo: os limites da participação e a (im) possibilidade de emancipação. Tese de doutorado. São Paulo: FAU-USP.

SILVA, M. K. [Mimeo]. "Trazendo os atores sociais de volta: pontos para uma agenda de pesquisa sobre ação coletiva, movimentos sociais e sociedade civil".

2007. "Dos objetos às relações: esboço de uma proposta teórico-metodológica para a análise dos processos de participação social no Brasil”. In: DAGNINO, E.; TATAGIBA, L. (orgs.). Democracia, sociedade civil e participação. Chapecó: Universitária.

2010. "De volta aos movimentos sociais? Reflexões a partir da literatura brasileira recente”. Ciências Sociais Unisinos, v. 46, n. 1, pp. 2-9. SOCIEDADE E ESTADO. 2006. Brasília: UnB, v. 21, n. 1.

TARROW, S. 1997. El poder in movimiento: los movimientos sociales, la acción colectiva y la política. Madri: Alianza Editorial.

TATAGIBA, L. 2004. "A institucionalização da participação: os conselhos municipais de políticas públicas na cidade de São Paulo”. In: AVRITZER, L. (org). A participação em São Paulo. São Paulo: Ed. da Unesp.

[No prelo]. "Relação entre movimentos sociais e instituições políticas no cenário brasileiro recente: reflexões em torno de uma agenda preliminar de pesquisa”. In: ALVAREZ, S. E.; BAIOCCHI, G.; LAÓMONTES, A.; RUBIN, J. W.; THAYER, M. (orgs.). Interrogating the civil society agenda: social movements, civil society and democratic innovation. .; TEIXEIRA, A. C. 2007. "O papel do CMH na política de habitação em São Paulo”. In: SANTORO, P.F.; CYMBALISTA, R.; TATAGIBA, L. e TEIXEIRA, A.C. Habitação: controle social e política pública. São Paulo: Instituto Pólis.

.; PATERNIANI, S. [No prelo]. "A militância do movimento de moradia da cidade de São Paulo: um retrato a partir do $11^{\circ}$ Encontro Estadual de Moradia Popular”. 
TILLY, C. 1978. From mobilization to revolution. Nova York: Newberry Award Records.

WAMPLER, B. 2010. "Transformando o Estado e a sociedade civil por meio da expansão das comunidades - política, associativa e de políticas públicas”. In: AVRITZER, L (org.). A dinâmica da participação local no Brasil. São Paulo, Cortez.

\section{Outros materiais}

MOVIMENTO PELO DIREITO À MORADIA. 2009. "Eleição do Conselho Municipal de Habitação: subprefeitura do M'Boi Mirim”. Disponível em <http: / www.youtube.com/watch?v=Xp6VFqGkUO0\&feature=play er_embedded\#at=565>. Acesso em 03/05/2010.

NOSSA SÃO PAULO. 2007. "Orçamento per capita e indicadores socioeconômicos por subprefeituras”. Disponível em <http://www. nossasaopaulo.org.br/portal/files/Orcamento_0.pdf >. Acesso em 28/06/2010.

PARTIDO POPULAR SOCIALISTA. 2009. "Eleição para o Conselho de Habitação da capital paulista será em 4 de outubro”. Disponível em <http://saopaulo.pps.org.br/portal/showData/159614>. Acesso em 01/02/2011.

PARTIDO DOS TRABALHADORES. 2007. "Boletim eletrônico da liderança do PT na Câmara Municipal de São Paulo”. Disponível em <http: / www. pt-camarasp.org.br/boletimpt483.html>. Acesso em 12/09/2009. 2009. "Eleição para o Conselho Municipal de Habitação". Disponível em <http:/ / www.youtube.com/watch?v=sUZ9iblgb68>. Acesso em 10/10/2009.

TUCANUSP. 2005. "Blog do núcleo do PSDB na USP". Disponível em $<$ http:/ / tucanusp.blogspot.com/2005/09/lua-de-mel-tem-seus-diascontados.html>. Acesso em 15/09/2009.

UNIÃO NACIONAL DOS MOVIMENTOS DE MORADIA. 2009. "Nota de protesto e repúdio da UMM em relação ao processo eleitoral do CMH-SP”. Disponível em <http:/ / www.sp.unmp.org.br/index.php?option=com_ content\&view=article\&id=407:nota-de-protesto-e-repudio-da-uniao-dosmovimentos-de-moradia-em-relacao-ao-processo-eleitoral-do-cmh-sp-de041009\&catid=41\&Itemid=94>. Acesso em 15/12/2009. 